\title{
Interaction between Kaolin and Urea in Organoclay and Its Impact on Removing Methylene Blue from Aqueous Solution
}

\author{
Sabri M. Husssein1, Omar H. Shihab², Sattar S. Ibrahim¹, Naser M. Ahmed ${ }^{3 *}$ \\ ${ }^{1}$ Department of Chemistry, College of Science, University of Anbar, Anbar, Iraq \\ ${ }^{2}$ Department of Chemistry, College of Women Education, University of Anbar, Anbar, Iraq \\ ${ }^{3}$ Nano-Optoelectronics Research and Technology Laboratory, School of Physics, University Sains Malaysia, \\ Penang, Malaysia \\ Email: ${ }^{*}$ naser@usm.my
}

Received 21 January 2015; accepted 6 February 2015; published 11 February 2015

Copyright (C) 2015 by authors and Scientific Research Publishing Inc.

This work is licensed under the Creative Commons Attribution International License (CC BY). http://creativecommons.org/licenses/by/4.0/

c) (7) Open Access

\begin{abstract}
Interaction between kaolin (particle size 53 and $106 \mu \mathrm{m}$ ) and urea was studied by infrared spectroscopy and powder X-ray diffraction. Interaction was found to be dependent on the particle size of kaolin raw material. Nature of interaction achieved through the formation of hydrogen bonds between urea and both $\mathrm{AlOH}$ and Si-O surface of kaolinite. Effect of temperature on equilibrium adsorption of methylene blue (MB) from aqueous solution using kaolin also studied, the results were analyzed by Langmuir and frendlich isotherms. Thermodynamic parameters such as $\Delta G, \Delta H$ and $\Delta S$ were calculated. Results suggested that the MB adsorption on kaolin was spontaneous and exothermic process.
\end{abstract}

Keywords

Kaolin, Urea, Intercalation, Thermodynamic, Methylene Blue and Adsorption

\section{Introduction}

Kaolin is one of the clay materials widely used in a large number of applications such as in ceramics, paper coating, paper filling, paint extender rubber filler, cracking catalyst or cements, oil refinery and water treatment (adsorption of dyes and other pollutant) [1]-[4] with the chemical composition $\mathrm{Al}_{2} \mathrm{Si}_{2} \mathrm{O}_{5}(\mathrm{OH})_{4}$. For each application the engineering properties of the clays must be carefully designed to obtain the desired result. Clays are

${ }^{*}$ Corresponding author.

How to cite this paper: Husssein, S.M., Shihab, O.H., Ibrahim, S.S. and Ahmed, N.M. (2015) Interaction between Kaolin and Urea in Organoclay and Its Impact on Removing Methylene Blue from Aqueous Solution. World Journal of Nano Science and Engineering, 5, 1-9. http://dx.doi.org/10.4236/wjnse.2015.51001 
usually defined as natural materials presenting fine granulometry. Often, these materials exhibit a lamellar structure as a consequence of the crystalline arrangement formed by the silicon and aluminum oxides, which are the main components of clays. These structures are displayed by these materials. Kaolinite is a common 1:1 dioctahedral phyllosilicate (clay) mineral found throughout the world in highly-weathered environments. Being a 1:1 mineral, it has one silica tetrahedral layer and one aluminum octahedral layer combine to form a unique structural arrangement in which sheets of tetrahedral and octahedral overlap each other, leading to structural changes such as 2:1 (one octahedral sheet between two tetrahedral sheets) and 1:1 (one tetrahedral sheet to one octahedral sheet) that characterize the various clay minerals [5] [6].

Kaolinite is a 1:1 tetrahedral aluminosilicate with two distinct basal cleavge faces. One of them consist of tetrahedral siloxane surface formed by very chemically inert Si-O-Si bonds, while the other constituted by an Octahedral sheet $\mathrm{Al}(\mathrm{OH})_{3}$ can be distributed and broken bands have the ability to accommodate $\mathrm{OH}$ group. The layers are bonded by hydrogen bonds. Hydrogen bonds occur between oppositely charged ends of a permanent dipole [7] [8].

Interaction between clays and organic compounds have received increase attention due to the wide ranges of applications especially in chromatography separations [9], to remove organic pollutants from air [10], and water [11], and to develop improved formulation for pesticides and as chemical sensor and molecular sieves [12].

This research primarily studies the nature intercalations between kaolinite and urea by using FTIR and XRD. Furthermore, it also studies the impacts to adsorption capacities made by the interaction, the kineticsod adsorption and application to remove dye from aqueous solution.

\section{Experimental}

Kaolinite used in this study was hydrated aluninum silicate, which was provided from general company for the manufacture of glass and ceramic (ceramic factory) in Ramadi. Chemical analysis of kaolin is shown in Table 1. Urea powder with a melting point of $132^{\circ} \mathrm{C}-135^{\circ} \mathrm{C}$, and density of $1.33 \mathrm{~g} / \mathrm{ml}$ was obtained from sigma Aldrich.

\subsection{Preparation of Kaolin-Urea Organoclay (Granular Size $53 \mu \mathrm{m}$ and $106 \mu \mathrm{m}$ )}

1. $70 \mathrm{gm}$ of grinded kaolin of granular size $53 \mu \mathrm{m}$ was weighed and placed in a Beaker (capacity of $500 \mathrm{ml}$ ).

2. $35 \mathrm{gm}$ of Urea was weighed and then added to the clay on the same Beaker.

3. The mixture was mixed by an electrical mixer in its dry form.

4. Suitable amount of water then added to the mixture with keeping continuous stirring, till getting a solution of kaolin-urea.

5. The mixture then placed at a porcelain crucible and heat in an oven at $90^{\circ} \mathrm{C}$ till dryness.

6. The products, finally was grinded and became ready to the required tests (FTIR, XRD and Adsorption of methylene blue (MB).

7. Same procedure was used on kaolin (partical size $106 \mu \mathrm{m}$ ).

\subsection{Preparation of Methylen Blue Solution}

$1 \mathrm{gm}$ of MB dye was dissolved in one liter of double distilled water to obtain $1000 \mathrm{ppm}$ MB dye solution. UVVis spectra of this solution appeared an absorption band at $\lambda_{\max }=660 \mathrm{~nm}$.

Table 1. Chemical analysis of kaolin.

\begin{tabular}{cc}
\hline $\mathrm{Al}_{2} \mathrm{O}_{3}$ & $>23 \%$ \\
$\mathrm{SiO}_{2}$ & $45 \%-50 \%$ \\
$\mathrm{Fe}_{2} \mathrm{O}_{3}$ & $<3 \%$ \\
$\mathrm{CaO}$ & $3 \%$ \\
$\mathrm{MgO}$ & $<2 \%$ \\
L.O.I & $12 \%-13 \%$ \\
\hline
\end{tabular}




\subsection{Steps of Adsorption}

- $0.5 \mathrm{gm}$ of the prepared organoclay was weighed, each alone and placed at $25 \mathrm{ml}$ volumetric flask.

- $10 \mathrm{ml}$ of methylen blue solution dye of the required concentration was added and stirred, very well to the clay.

- The flasks were placed at shaker water bath at different temperatures $\left(10^{\circ} \mathrm{C}, 30^{\circ} \mathrm{C}, 40^{\circ} \mathrm{C}\right.$ and $\left.50^{\circ} \mathrm{C}\right)$ and stirred for 1 hour each.

- The solutions were filtered.

- The absorption was measured for each filtrate at $660 \mathrm{~nm}$.

- The adsorption required calculation according to (Langmuir and Freundlich isotherms), from which the thermodynamic constant can be obtained $(\Delta \mathrm{G}, \Delta \mathrm{H}$ and $\Delta \mathrm{S})$.

\subsection{Preparation of Nano Organoclays}

1) Weigh $5 \mathrm{~g}$ of prepared organoclay and placed in a glas Baker $250 \mathrm{ml}$.

2) Added $200 \mathrm{ml}$ of a solution of urea concentration $2 \mathrm{M}$ and shake well.

3) The solution is placed on the ultrasonic (probe ultrasonic) and placed the amount of ice around the beaker for one hour.

4) Separating the precipitate from the filtrate using a centrifuge.

5) Dried the pricipitate and then grinds it and conducted the tests required.

6) Returned the same previous steps for (Thiourea, Acetamide, DMSO and DMF).

\section{Results and Discussion}

\subsection{FTIR Results}

Vibrational spectroscopy is a key technique in the study of formation and structural characterization of kaolinite intercalates [13].

FTIR of kaolin, urea and kaolin-urea complex are shown in Figure 1 and Figure 2. From these figures, one could observed that kaolin show two sharp bands at $3694 \mathrm{~cm}^{-1}$ and $3625 \mathrm{~cm}^{-1}$. The literature however shows conflicting assignment of these bands [14], band at $3694 \mathrm{~cm}^{-1}$ belong to hydroxyl group in specific lattice sites in the layer and resulting from vibrational coupling of three surface of hydroxyl in the primitive cell and the dipole oscillation in perpendicular to the layer, while band at $3625 \mathrm{~cm}^{-1}$ in belong to hydroxyl group lie within lamellae

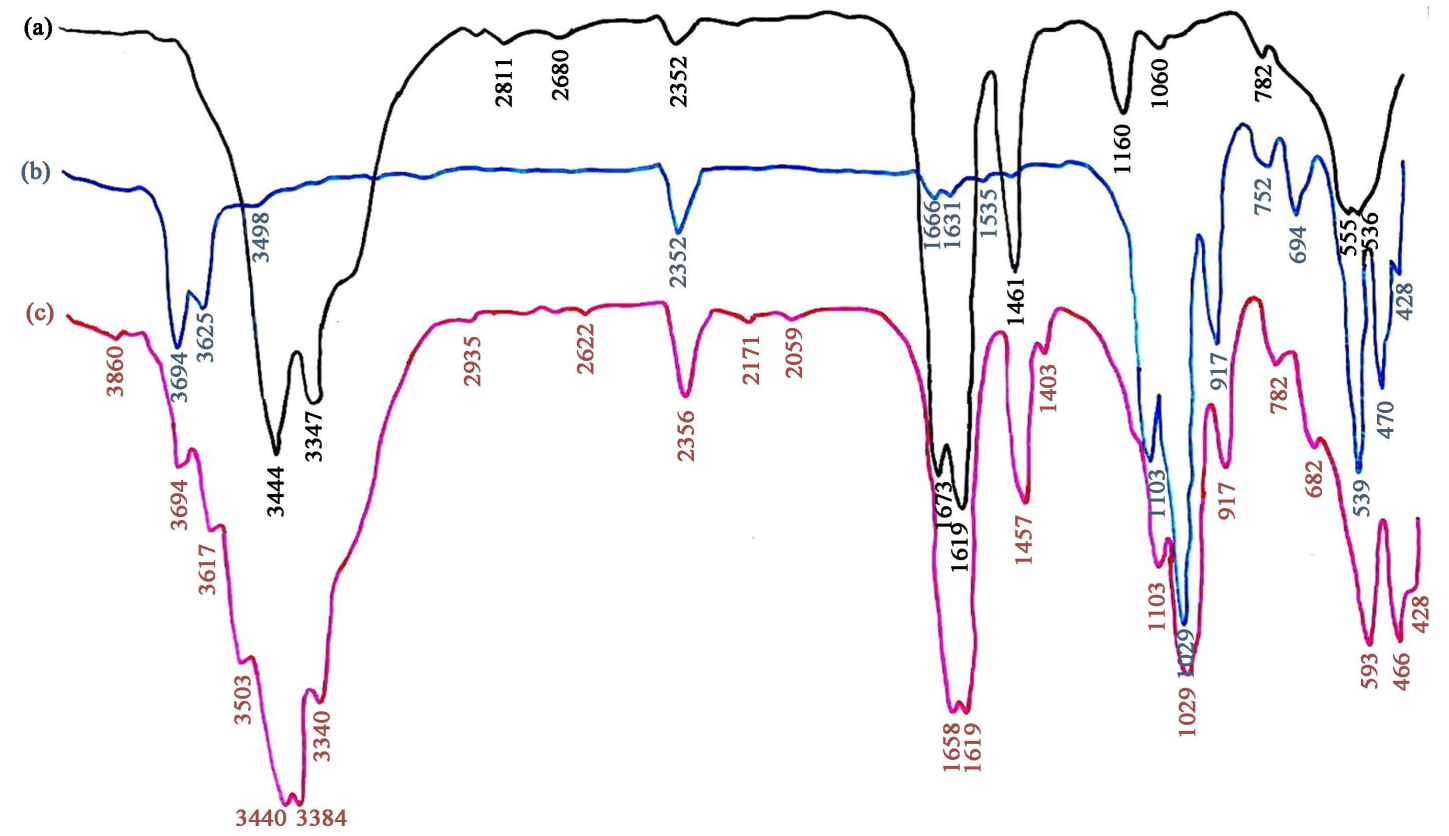

Figure 1. FTIR spectra of (a) urea; (b) kaolin $53 \mu \mathrm{m}$ and (c) kaolin $53 \mu \mathrm{m}$-urea complex. 


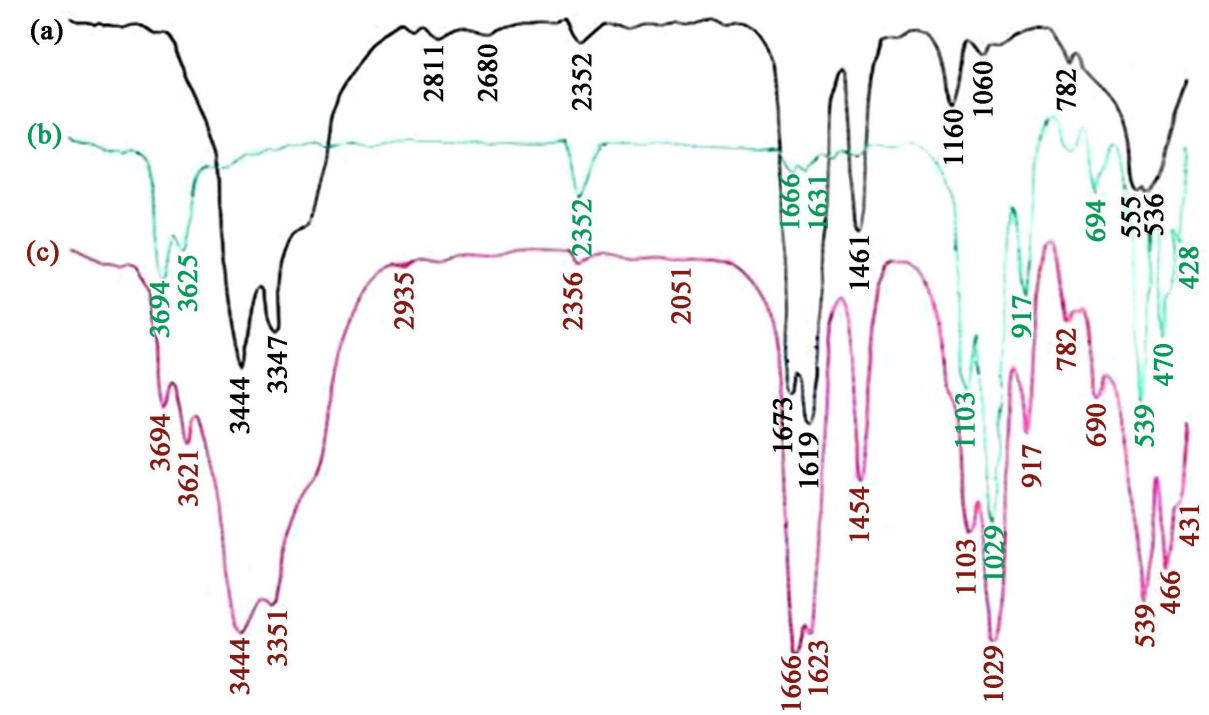

Figure 2. FTIR spectra of (a) kaolin $106 \mu$ m; (b) urea and (c) kaolin $106 \mu$ m-urea complex.

in plane common to both the tetrahedral and octahedral sheets. Upon intercalation with urea, the intensity of these two bands decrease and shifted to lower frequency, Also a new bands at $3503 \mathrm{~cm}^{-1}$ appeared due to the breaking of some hydrogen bonds between the kaolinite layers and formation of new band, which usually involve the inner surface $\mathrm{OH}$ group and change are observed in the intensities of bands assigned to vibrations of these groups [13].

Bands at 3440 and $3444 \mathrm{~cm}^{-1}$ in the Figure 1 and Figure 2 (Chart C) which appear in the results intercalation of kaolinite 53 and $106 \mu \mathrm{m}$ with urea respectively are attributed to formation $\mathrm{H}$-bond between $\mathrm{NH}_{2}$ group from urea and Oxygen group of tetrahedral sheet for kaolinite.

The newly formed bands at 3384 and $3503 \mathrm{~cm}^{-1}$ in the intercalation of kaolinite $53 \mu \mathrm{m}$ with urea confirmed the asymmetric and symmetric $\mathrm{NH}_{2}$ stretching frequencies involved in weak H-bonding with the inner hydroxyls [15]-[18].

Band at $2352 \mathrm{~cm}^{-1}$ in urea chart and kaolinite 53 and $106 \mu \mathrm{m}$ started disappear when intercalated urea with kaolinite $106 \mu \mathrm{m}$ and happened shifted in this band to the $2356 \mathrm{~cm}^{-1}$ when intercalate urea with kaolinite $53 \mu \mathrm{m}$.

Also same effect appeared for the band at $1673 \mathrm{~cm}^{-1}$, which assigned for the $\mathrm{C}=\mathrm{O}$ group of urea, upon interaction with kaolin, formation a bond between $\mathrm{C}=\mathrm{O}$ and $\mathrm{OH}$ group in Gibbsite-like layer so it shifted to 1658 and $1666 \mathrm{~cm}^{-1}$ whene kaolinite 53 and $106 \mu \mathrm{m}$ interactions with urea respectinely (Chart C in Figure 1 and Figure 2). CN stretching of free urea appeared at $1461 \mathrm{~cm}^{-1}$, upon interaction with kaolinite shifted to 1457 and $1454 \mathrm{~cm}^{-1}$ in the Figure 1 and Figure 2 Chart $C$ respectively, and a new band at $1403 \mathrm{~cm}^{-1}$ appeared. This suggest urea in this system would then be considered to exist in two forms anionic and complex (ion dipole) as shown in Figure 3.

\subsection{XRD Results}

The XRD curves of raw kaolin chart (A), and kaolin-Urea complexes charts (B and C) are shown in Figure 4.

From this figure one could observe that the strongest three peaks and their values are recorded in Table 2.

From this table:

Peaks at $2 \theta=12.3044, \mathrm{~d}(\AA)=7.18765$, intensity $=403$ and $2 \theta=24.9208, \mathrm{~d}(\AA)=3.57009$, intensity $=362$ are attributed to kaolinite and $2 \theta=26.6345, \mathrm{~d}(\AA)=3.34415$, intensity $=286$ is due to $\mathrm{SiO}_{2}$.

Peak in Chart $B$ at $2 \theta=22.4669, d(\AA)=3.95417$, intensity $=1019$ is attributed to urea, and peaked at $2 \theta=$ 268558, $d(\AA)=3.31709$, intensity $=247$ is due to $\mathrm{SiO}_{2}$. Band at $2 \theta=25.1508, \mathrm{~d}(\AA)=3.53796$, intensity $=227$ is due to kaolinite.

These peaks in Chart $\mathrm{C}$ at $2 \theta=22.3047, \mathrm{~d}(\AA)=3.98256$, intensity $=2249,2 \theta=29.3554, \mathrm{~d}(\AA)=3.04008$, intensity $=371$ and $2 \theta=24.6676, \mathrm{~d}(\AA)=3.60616$, intensity $=370$ are assigned to urea, $\mathrm{SiO}_{2}$ and kaolinite respectively.

From the results in Table 2 and make comparison between these values, on could concluded that strong intercalation between kaolinite layers and urea as a result of appearance high intensity of peaks are due to urea and 
<smiles>NC(N)=O</smiles>

I<smiles>NC(=[NH2+])[O-]</smiles>

II<smiles>NC(=[NH2+])[O-]</smiles>

III

Figure 3. Anionicformsin ureamolecule.

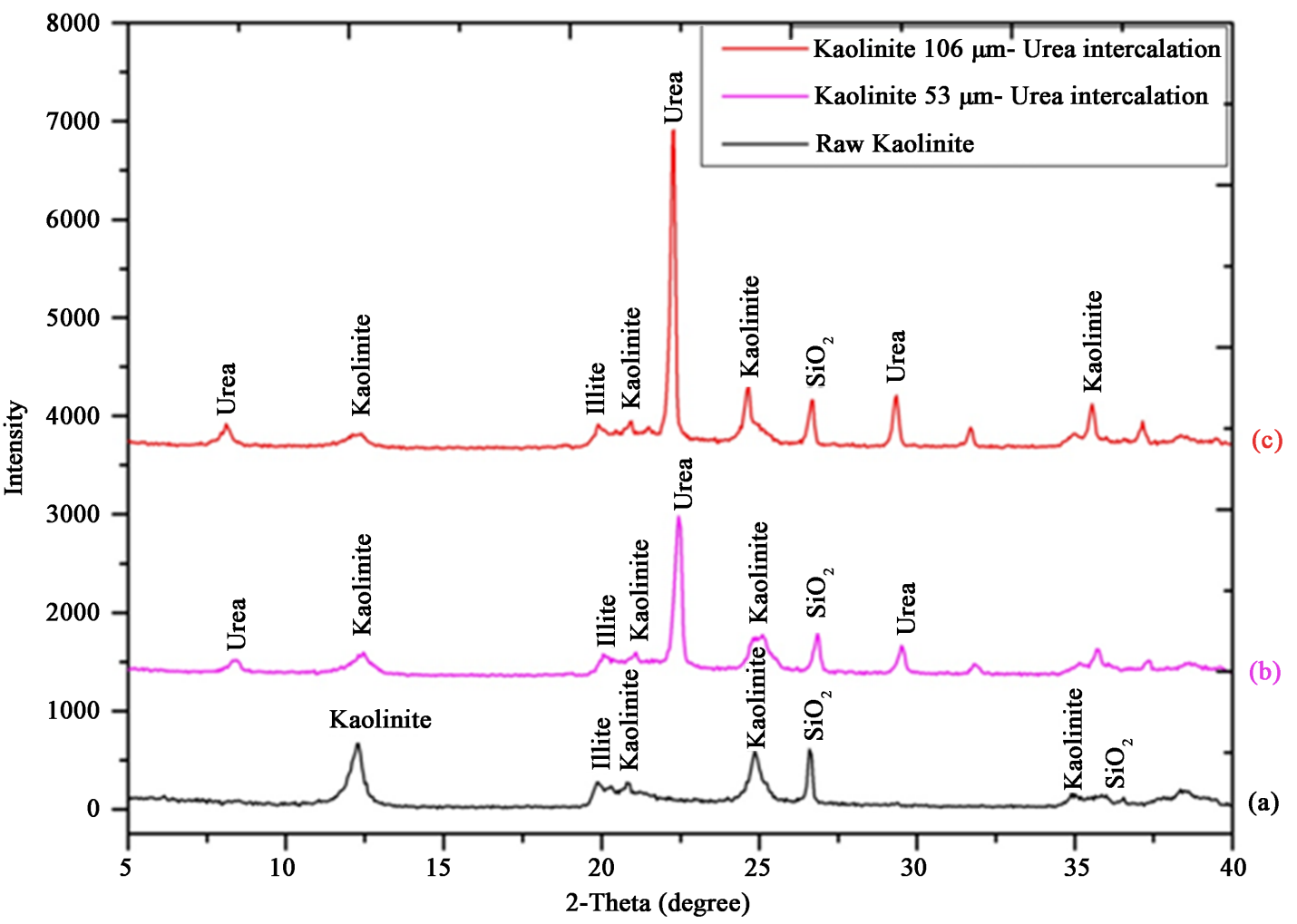

Figure 4. The XRD pattern of raw kaolinite (a); kaolinite $53 \mu$ m-urea intercalation (b); and kaolinite $106 \mu$ m-urea intercalation (c).

Table 2. Values of XRD for strong peaks in Figure 4 Chart A.

\begin{tabular}{|c|c|c|c|}
\hline Assignment & Kaoline & Kaolinite $53 \mu \mathrm{m}$-Thiourea Complex & Kaolinite $53 \mu \mathrm{m}$-Thiourea Complex \\
\hline \multirow{4}{*}{$2 \theta$} & 12.3044 & 22.4669 & 22.3047 \\
\hline & 24.9208 & 26.8558 & 29.3554 \\
\hline & 26.6345 & 25.1508 & 24.6676 \\
\hline & 7.18765 & 3.95417 & 3.98256 \\
\hline \multirow[t]{2}{*}{ d-spacing d( $(\AA)$} & 3.57009 & 3.31709 & 3.04008 \\
\hline & 3.34415 & 3.53796 & 3.60616 \\
\hline \multirow{3}{*}{ Intensity (counts) } & 403 & 1019 & 2249 \\
\hline & 362 & 247 & 371 \\
\hline & 286 & 227 & 370 \\
\hline
\end{tabular}


in the same time happened shifted and decrease in the intensity of kaolinite and $\mathrm{SiO}_{2}$ when the intercalation is event. The intercalation caused the destruction of the hydrogen bonding between the kaolinite layers [14]. And from results in this table show decreasing in intensity of peaks when the kaolin $53 \mu \mathrm{m}$-urea intercalated with urea compared with other complex this indicates that this kaoline a granular size $53 \mu \mathrm{m}$ is the best.

\subsection{Adsorption Results}

Effects of temperature on the equilibrium adsorption of methylene blue from aqueous solution using kaolin (partical size 53 and $106 \mu \mathrm{m}$ ) and kaolin-urea complex were studied.

The equilibrium adsorption data were analyzed using two widely applied isotherms: Langmuir and Freundlich. The results were shown in Table 3 and Table 4. Non-linear method was used for comparing the best fit of the isotherms. Best fit was found to be Langmuir isotherm.

\subsubsection{Thermodynamic Parameters}

Thermodynamic parameters such as $\Delta \mathrm{G}, \Delta \mathrm{H}$ and $\Delta \mathrm{S}$ were calculated using adsorption equilibrium constant obtained from Langmuir isotherm and shown in Table 5.

Results suggested that methylene blue adsorption on kaolin was spontaneous and exothermic process.

Decrease a negative value of $\Delta \mathrm{G}$ with increase the value of $\Delta \mathrm{H}$ (-ve) indicate that the adsorption reaction was exothermic.

Percentage of adsorption (Q\%) for kaolin and kaolin-urea at conc. 100 ppm of methylen blue are shown in Table 6.

\subsubsection{Transmission Electron Microscopy (TEM)}

TEM is a microscopy technique in which a beam of electrons is transmitted through an ultra-thin specimen, interacting with the specimen as it passes through. An image is formed from the interaction of the electrons transmitted through the specimen; the image is magnified and focused onto an imaging device, such as a fluorescent screen, on a layer of photographic film, or to be detected by a sensor such as a CCD camera.

Figure 5 and Figure 6 show the TEM photographs of Kaolin (53 and $106 \mu \mathrm{m}$ )-urea complexes.

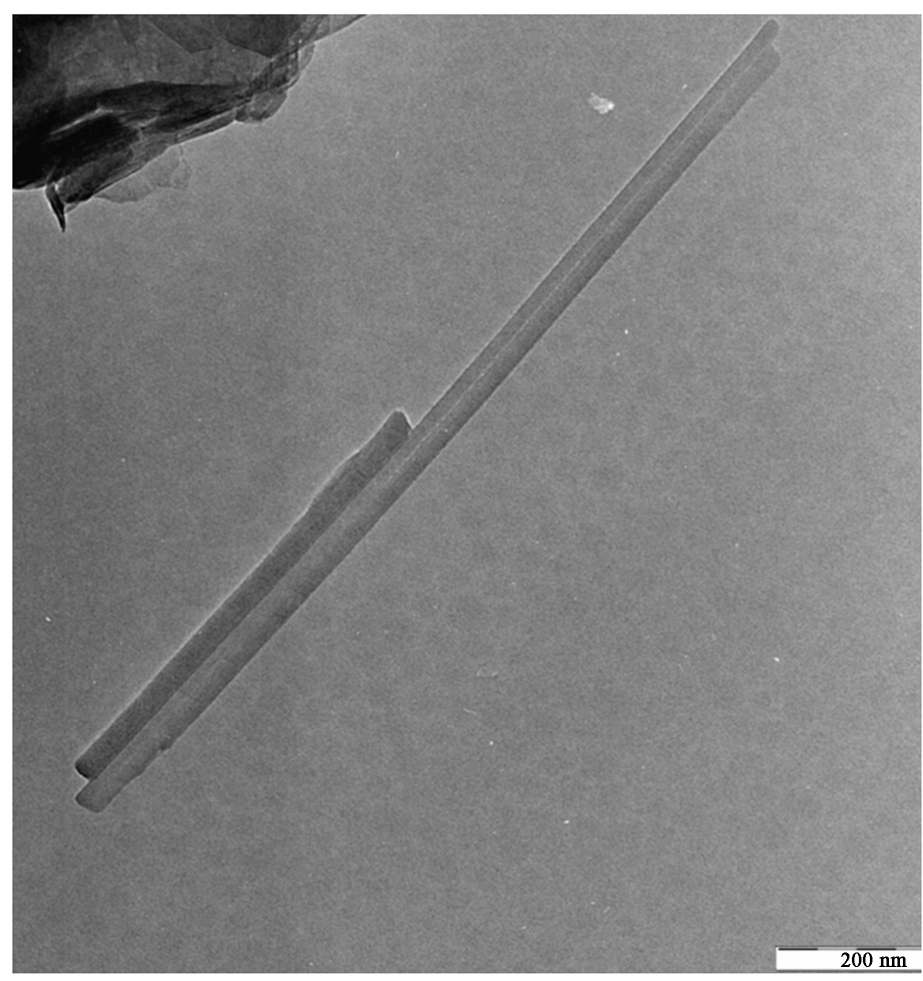

Figure 5. TEM image of kaolinite $53 \mu \mathrm{m}$ urea complexes. 


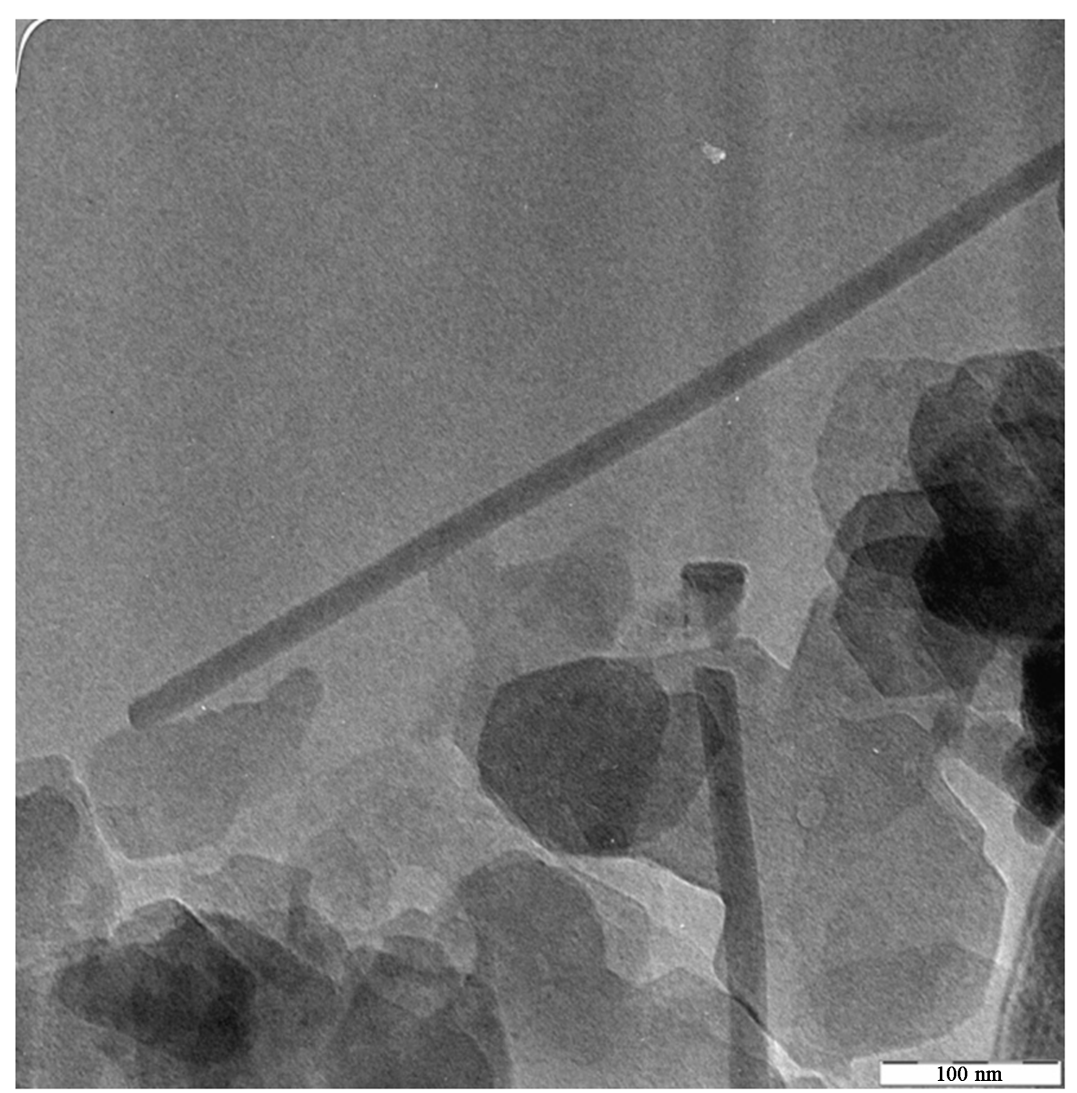

Figure 6. TEM image of kaolinite $106 \mu \mathrm{m}$ urea complexes.

Table 3. Langmuir constant for adsorption at conc. 100 ppm of methylene blue.

\begin{tabular}{|c|c|c|c|c|c|c|}
\hline \multirow{2}{*}{ Sample } & \multirow{2}{*}{ Particle Size $\mu \mathrm{m}$} & \multirow{2}{*}{ Langmuir Constant } & \multicolumn{4}{|c|}{ Temperature K } \\
\hline & & & 283 & 303 & 313 & 322 \\
\hline \multirow{3}{*}{ Kaolin } & \multirow{3}{*}{53} & $\mathrm{~K}_{\mathrm{f}}$ & 1000 & 1000 & 1000 & 500 \\
\hline & & a & 1 & 1 & 1 & 0.5 \\
\hline & & $\mathrm{R}^{2}$ & 0.535 & 0.411 & 0.504 & 0.64 \\
\hline \multirow{3}{*}{ Kaolin-Urea } & \multirow{3}{*}{53} & $\mathrm{~K}_{\mathrm{f}}$ & 0 & 0 & 0 & 0 \\
\hline & & a & 0 & 0 & 0 & 0 \\
\hline & & $\mathrm{R}^{2}$ & 0.758 & 0.879 & 0.944 & 0.957 \\
\hline \multirow{3}{*}{ Kaolin } & \multirow{3}{*}{106} & $\mathrm{~K}_{\mathrm{f}}$ & 0 & 250 & 142.857 & 250 \\
\hline & & $\mathrm{a}$ & 0 & -1.5 & -1.714 & -0.5 \\
\hline & & $\mathrm{R}^{2}$ & 0.817 & 0.933 & 0.933 & 0.345 \\
\hline \multirow{3}{*}{ Kaolin + Urea } & \multirow{3}{*}{106} & $\mathrm{~K}_{\mathrm{f}}$ & 1000 & 1000 & 500 & 500 \\
\hline & & a & 2.0 & 3.0 & 1.5 & 0.5 \\
\hline & & $\mathrm{R}^{2}$ & 0.65 & 0.737 & 0.808 & 0.640 \\
\hline
\end{tabular}


Table 4. Freundlich constant for adsorption at conc. 100 ppm of methylene blue.

\begin{tabular}{|c|c|c|c|c|c|c|}
\hline \multirow{2}{*}{ Sample } & \multirow{2}{*}{ Particle Size $\mu \mathrm{m}$} & \multirow{2}{*}{ Freundlich Constant } & \multicolumn{4}{|c|}{ Temperature K } \\
\hline & & & 283 & 303 & 313 & 322 \\
\hline \multirow{3}{*}{ Kaolin } & \multirow{3}{*}{53} & $\mathrm{~K}_{\mathrm{f}}$ & 419.75 & 404.57 & 309.2 & 285.759 \\
\hline & & $\mathrm{n}$ & 1.315 & 1.207 & 1.331 & 1.360 \\
\hline & & $\mathrm{R}^{2}$ & 0.913 & 0.938 & 0.897 & 0.864 \\
\hline \multirow{3}{*}{ Kaolin-Urea } & \multirow{3}{*}{53} & $\mathrm{~K}_{\mathrm{f}}$ & 371.53 & 297.85 & 229.08 & 186.638 \\
\hline & & $\mathrm{n}$ & 1.680 & 1.980 & 2.624 & 2.923 \\
\hline & & $\mathrm{R}^{2}$ & 0.860 & 0.876 & 0.867 & 0.877 \\
\hline \multirow{3}{*}{ Kaolin } & \multirow{3}{*}{106} & $\mathrm{~K}_{\mathrm{f}}$ & 319.15 & 1127.19 & 1879.31 & 434.51 \\
\hline & & $\mathrm{n}$ & 1.751 & 0.536 & 0.379 & 1.360 \\
\hline & & $\mathrm{R}^{2}$ & 0.880 & 0.983 & 0.970 & 0.864 \\
\hline \multirow{3}{*}{ Kaolin-Urea } & \multirow{3}{*}{106} & $\mathrm{~K}_{\mathrm{f}}$ & 263.02 & 224.38 & 207.01 & 202.301 \\
\hline & & $\mathbf{n}$ & 1.633 & 1.908 & 1.754 & 1.481 \\
\hline & & $\mathbf{R}^{2}$ & 0.885 & 0.874 & 0.924 & 0.920 \\
\hline
\end{tabular}

Table 5. Thermodynamic parameters at conc. 100 ppm Methylen blue.

\begin{tabular}{|c|c|c|c|c|c|c|c|}
\hline \multirow{2}{*}{ Sample } & \multirow{2}{*}{ Particle Size $\mu \mathrm{m}$} & \multirow{2}{*}{$\underset{\mathbf{K J} / \mathbf{m o l}}{\Delta \mathbf{H}}$} & \multirow{2}{*}{$\begin{array}{c}\Delta S \\
\mathbf{K J} / \mathbf{m o l} \cdot \mathbf{k}\end{array}$} & \multicolumn{4}{|c|}{$\Delta \mathrm{G} \mathrm{KJ} / \mathrm{mol}$} \\
\hline & & & & $283 \mathrm{~K}$ & $303 \mathrm{~K}$ & $313 \mathrm{~K}$ & $322 \mathrm{~K}$ \\
\hline Kaolin & 53 & -9.877 & 0.01858 & -15.0757 & -15.7056 & -15.644 & -15.8984 \\
\hline Kaolin-Urea & 53 & -6.59965 & 0.0325576 & -15.661 & -16.668 & -17.119 & -18.742 \\
\hline Kaolin & 106 & -16.9356 & -0.006187 & -15.3088 & -14.8637 & -14.8618 & -15.1733 \\
\hline Kaolin-Urea & 106 & -9.935 & 0.01738 & -14.6689 & -15.6398 & -15.904 & -16.2948 \\
\hline
\end{tabular}

Table 6. Percentage of adsorption (Q\%) for kaolin and kaolin-urea at conc. 100 ppm of methylen blue.

\begin{tabular}{|c|c|c|c|c|c|}
\hline \multirow{2}{*}{ Sample } & \multirow{2}{*}{ Particle Size $\mu \mathrm{m}$} & \multicolumn{4}{|c|}{ Q\% at Different Temp. } \\
\hline & & $283 \mathrm{~K}$ & $303 \mathrm{~K}$ & $313 \mathrm{~K}$ & $322 \mathrm{~K}$ \\
\hline Kaolin & 53 & 99.853 & 99.803 & 99.7521 & 99.726 \\
\hline Kaolin-Urea & 53 & 99.8714 & 99.8662 & 99.861 & 99.803 \\
\hline Kaolin & 106 & 99.8506 & 99.726 & 99.699 & 99.648 \\
\hline Kaolin-Urea & 106 & 99.8039 & 99.7987 & 99.7313 & 99.6639 \\
\hline
\end{tabular}

From this figures show formation of nanotubeit is also very clearly in the images. The average sizes of particles are in the range of 20.2 - $24.5 \mathrm{~nm}$ in Figure 5 and from 20.8 - $27.7 \mathrm{~nm}$ in Figure 6.

\section{References}

[1] Belver, C., Munor, M.A. and Vicente, M.A. (2002) Chemical Activation of a Kaolinite under Acid and Alkaline Conditions. Chemistry of Materials, 14, 2033-2043. http://dx.doi.org/10.1021/cm0111736

[2] Vaga, G. (2007) Effect of Acid Treatments on the Physicochemical Properties of Kaolin Clay. Epitoanyag, 59, 4-8. 
[3] Caulcante, A.M., Torres, L.G. and Welho, G.L.V. (2005) Effect of Acid Treatments on the Physicochemical Properties of Kaolin Clay. Journal of Chemical Engineering, 22, 2682-2865.

[4] Salawudeen, T.O., Dada, E.O. and Alagbe, S.O. (2007) Performance Evaluation of Acid Treated Clays for Palm Oil Bleaching. Journal of Engineering and Applied Sciences, 2, 1677-1680.

[5] Grim, R.E. (1962) Clay Mineralogy. McGraw Hill, New York.

[6] Valenzuela-Díaz, F.R., Souza-Santos, P. and Souza-Santos, H. (1992) A importância das argilas industriais brasileiras II. Quimica Industrial, 44, 31-35.

[7] Fell, J.R., MacGregor, P., Stapledon, D. and Bell, G. (2005) Geotechnical Engineering of Dams. A. A. Balkema, Leiden.

[8] Mitchell, J.K. and Soga, K. (2005) Fundamentals of Soil Behavior. 3rd Edition, John Wiley \& Sons, Hoboken.

[9] Wang, Y., Chem, F.B. and Wu, K.C. (2004) Twin-Screw Extrusion Compounding of Polypropylene/Organoclay Nanocomposites Modified by Maleated Polypropylenes. Journal of Applied Polymer Science, 93, 100-112. http://dx.doi.org/10.1002/app.20407

[10] Sonawane and Meshram, S. (2011) Photo Catalytic Dehydration of Phenol Using ZnO Nanoclay under UV Irradiation in CSTR. Chemical Engineering Journal, 72, 632-637.

[11] Xiang, Y.B., Wang, N., Song, J.M., Cai, D.Q. and Wu, Z.Y. (2013) Micro-Nanopores Fabricated by High-Energy Electron Beam Irradiation: Suitable Structure for Controlling Pesticide Loss. Journal of Agricultural and Food Chemistry, 61, 5215-5219.

[12] Al-Marsoumi Sabri, M.H. and Farouk, K. (2010) Improving the Properties Iraqi Kaoline as an Alternative to the Plastic Clay. Patent No. 2143.

[13] Farmer, V.C. (2000) Transverse and Longitudinal Crystal Modes Associated with OH Stretching Vibrations in Single Crystals of Kaolinite and Dickite. Spectrochimica Acta Part A, 56, 927-930. http://dx.doi.org/10.1016/S1386-1425(99)00182-1

[14] Frost, R., Kristof, J., Rintoul, L. and Kloprogge, J. (2000) Raman Spectroscopy of Urea and Urea-Intercalation Kaolinite at 77 K. Spectrochimica Acta Part A, 56, 1681-1691. http://dx.doi.org/10.1016/S1386-1425(00)00223-7

[15] Orzechowski, K., Stonka, T. and Glowinski, J. (2006) Dielectric Properties of Intercalated Kaolinite. Journal of Physics and Chemistry of Solids, 67, 915-919. http://dx.doi.org/10.1016/j.jpcs.2006.03.001

[16] Ledoux, R.L. and White, J.L. (1966) Infrared Studies of Hydrogen Bonding Interaction between Kaolinite Surfaces and Intercalated Potassium Acetate, Hydrazine, Formamide, and Urea. Journal of Colloid and Interface Science, 21, 127152. http://dx.doi.org/10.1016/0095-8522(66)90029-8

[17] Zhu, X.Y., Yan, C.J. and Chen, J.Y. (2012) Application of Urea-Intercalated Kaolinite for Paper Coating. Applied Clay Science, 55, 114-119. http://dx.doi.org/10.1016/j.clay.2011.11.001

[18] Valaskova, M., Barabaszova, K., Hundakova, M., Ritz, M. and Plevova, E. (2011) Effects of Brief Milling and Acid Treatment on Two Ordered and Disordered Kaolinite Structures. Applied Clay Science, 54, 70-76. http://dx.doi.org/10.1016/j.clay.2011.07.014 
Scientific Research Publishing (SCIRP) is one of the largest Open Access journal publishers. It is currently publishing more than 200 open access, online, peer-reviewed journals covering a wide range of academic disciplines. SCIRP serves the worldwide academic communities and contributes to the progress and application of science with its publication.

Other selected journals from SCIRP are listed as below. Submit your manuscript to us via either submit@scirp.org or Online Submission Portal.
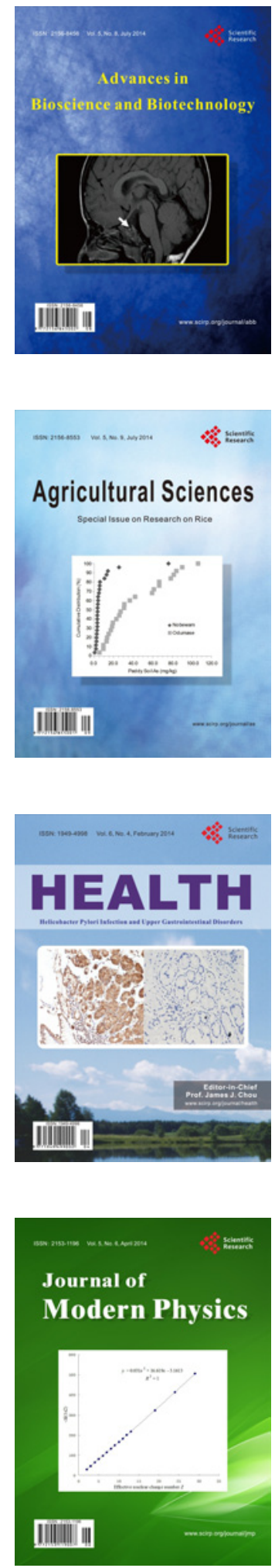
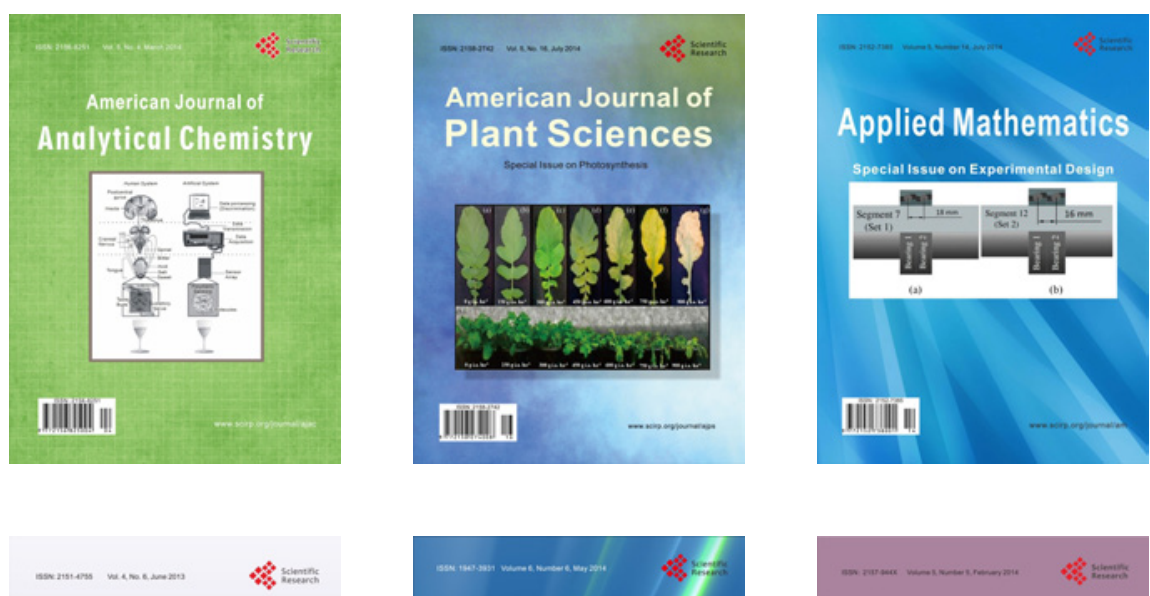

Creative Education
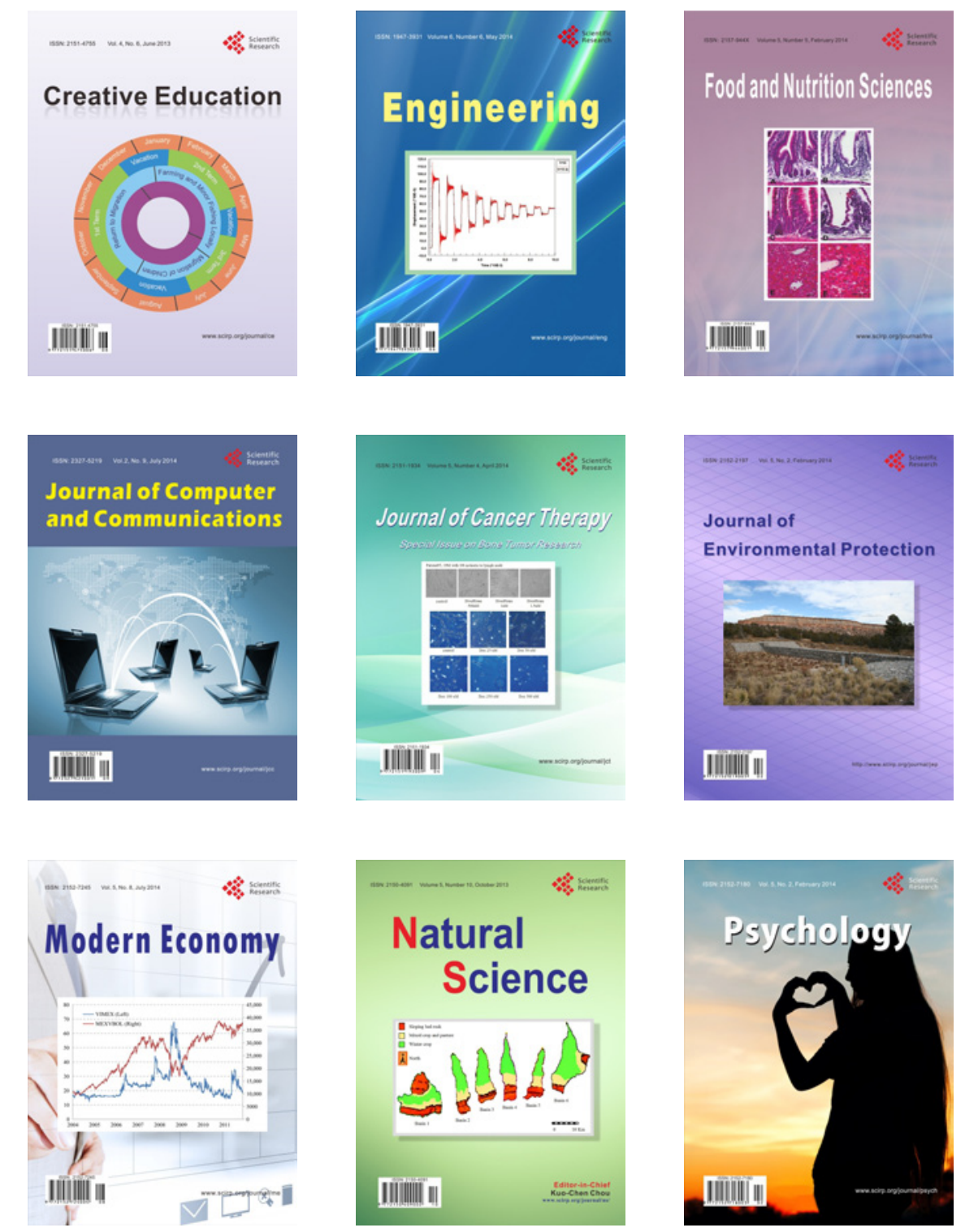